\title{
Propagandastudier: Kooperativa förbundet, demokratin och det fria tankelivet på 1930-talet
}

\author{
Petter Tistedt
}

\begin{abstract}
Propaganda Studies: The Swedish Cooperative Union, Democracy, and Free Thinking in the 1930s. - This article investigates educational efforts of the Swedish Cooperative Union (Kooperativa förbundet, KF) during the late interwar period. It focuses on how KF dealt with the fact that propaganda could be a very effective tool of persuasion - e.g. as commercial advertising - but that it also could undermine democracy. For KF, a prolific and innovative advertiser as well as a strong proponent of democratic ideals, this was a real conundrum. Using study guides, books and journals published by $\mathrm{KF}$ as sources, this article investigates how members of its study groups were instructed to think about propaganda and its role in society. It is argued that members were taught a form of critical acceptance of propaganda, one that not only legitimized its role in the market, but in democratic public life as well.
\end{abstract}

Keywords • Swedish Cooperative Union [Kooperativa förbundet], Education [utbildning], Propaganda; Advertising [reklam], 1930s [1930-talet]

\section{Introduktion: ett aktuellt ämne}

Hösten 1935 publicerade Kooperativa förbundet (KF) den senaste i en rad handledningar i ekonomi, samhällskunskap och kooperativt arbete för förbundets gruppstudier. Turen var kommen till ett "utomordentlig aktuellt" ämne som, enligt annonseringen, "berör intimt var och en". " Ämnet var propaganda. Syftet var, som handledningen formulerade det, "att förstå, hur det kommer sig, att propaganda av skiftande art kan ha så stor makt över sinnena, som faktiskt är fallet i vår tid."' Som kursbok användes folkbildaren Alf Ahlbergs Tankelivets frigörelse från 1934, även den publicerad av KF. Boken var en kritisk genomlysning av samtida propaganda och reklam - något som vid denna tid förstods som i grunden samma sak - vars hot mot ett fritt och demokratiskt tanke- och samhällsliv Ahlberg bedömde som mycket

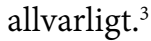

KF karakteriserades av starka demokratiska normer och hade som mål att skapa "rationella konsumenter", och mot den bakgrunden är det inte förvånande att propaganda kunde uppfattas som ett problem. ${ }^{4}$ De slutsatser om behovet av kritiskt

\footnotetext{
1 "Ny handledning i högaktuellt ämne," Vi vill 1935:9 upplaga A, 8.

2 Herman Stolpe och Holter Sohlenius, Propagandafrågor: Handledning för de kooperativa gruppernas diskussioner (Stockholm: KF, 1935), 1.

3 Alf Ahlberg, Tankelivets frigörelse (Stockholm: KF, 1934).

4 Peder Aléx, Den rationella konsumenten: KF som folkuppfostrare 1899-1939 (Stockholm: Symposion, 1994).
}

Petter Tistedt (PhD) is a Researcher at the Department of History of Science and Ideas, Uppsala University, Sweden.

Email: petter.tistedt@idehist.uu.se. 
tänkande och farorna med propaganda som allt mer integrerades i diskussionerna om den svenska skolan efter andra världskriget, var redan under mellankrigstiden viktiga för KF. ${ }^{5}$ Samtidigt bedrev dock KF självt omfattande kampanjer för att övertyga om kooperationens samhällsnytta, värva medlemmar och locka kunder, ett arbete som deltagarna i gruppstudierna förutsattes delta i. Det var ett arbete som även av KF förstods som just "propaganda", ett ord som alltså inte nödvändigtvis hade de negativa konnotationer som Ahlberg fäste vid det, eller som vi är vana vid idag. ${ }^{6}$ Men redan i samtiden var det uppenbart att här fanns verkligen ett problem som inte bara handlade om ordval: hur skulle avvägningen göras mellan effektivitet och demokratisk legitimitet i en offentlig kommunikation som syftade till att påverka tänkesätt och handlingar?

I syfte att visa hur KF hanterade detta dilemma mellan effektivitet och demokratisk legitimitet besvarar undersökningen tre frågor: Varför skulle KF:s medlemmar studera propaganda? Hur skulle deltagarna lära sig? Vad skulle de lära sig? Svaren på dessa frågor ger inte bara ny kunskap om KF:s studieverksamhet och de teoretiska och praktiska överväganden som underbyggde den. Svaren bidrar också till kunskapen om hur reklam och propaganda etablerades som en acceptabel eller till och med önskvärd del av inte bara en marknadsekonomi utan även av en demokratisk kultur. 1930-talet var en särskilt intensiv period i båda fallen: ambitionen och omfattningen av KF:s studier tilltog påtagligt, den internationella kooperativa rörelsen liksom den politiska demokratin stod under tryck från de nya diktaturerna, och reklambranschen expanderade sitt ekonomiska och kulturella utrymme. KF:s propagandastudier leder rätt in i den problematik som formerades i skärningspunkten mellan dessa processer.

Flera historiska undersökningar har på senare tid, delvis i polemik mot tidigare studier, framhållit att det inte fanns en nödvändig motsättning mellan reklamens metoder och kooperativa principer. ${ }^{7}$ Men som forskningen också noterat fördes interna kritiska diskussioner kring hur prioriteringar och avvägningar skulle göras ifråga om propagandan, inklusive den kommersiella. ${ }^{8}$ Hur KF liksom kooperationen i andra länder hanterade detta är i stort okänt, och det gäller särskilt hur propaganda gjordes till en praktisk angelägenhet i medlemsupplysningen. Undersökningar om KF:s propaganda och reklam som utesluter detta utelämnar i själva verket en central dimension, inte minst eftersom det var deltagarna i studierna som själva skulle bedriva mycket av den kooperativa propagandan.

Historiska undersökningar om kooperationens studieverksamhet - också det ett

5 Om skolan, se Johan Östling, Nazismens sensmoral: Svenska erfarenheter $i$ andra världskrigets efterdyning (Stockholm: Atlantis, 2008), 152-74.

6 Elin Gardeström, Reklam och propaganda under svenskt 1930-tal (Huddinge: Södertörns högskola, 2018), kap. 5.

7 Pernilla Jonsson, "From Commercial Trickery to Social Responsibility: Marketing in the Swedish Co-operative Movement in the Early Twentieth Century," i Mary Hilson, Silke Neunsinger och Greg Patmore, red., A Global History of Consumer Co-operation: Movements and Businesses (Boston: Brill, 2017); Stefan Schwarzkopf, "Innovation, Modernisation, Consumerism: The Cooperative Movement and the Making of British Advertising and Marketing Culture, 1890s-1960s," i Consumerism and the Co-operative Movement in Modern British History: Taking Stock, red. Lawrence Black och Nicole Robertson (Manchester: Manchester University Press, 2009).

8 Gardeström (2018), 130-31; Mary Hilson, "Co-operative History: Movements and Businesses," i Hilson, Neunsinger och Patmore (2017), 28-29; Jonsson (2017), 665-67; Schwarzkopf (2009), 206. 
eftersatt område, även inom forskningen om kooperativa rörelser i andra länder har å sin sida inte utrett hur den förhöll sig till de frågor om propaganda och demokrati som denna artikel behandlar. ${ }^{9}$ All forskning om KF:s medlemsupplysning har god hjälp av idéhistorikern Peder Aléx avhandling. Den har emellertid en slagsida mot ett ovanifrånperspektiv, genom den centrala roll som tilldelas avsiktsförklaringar och programmatiska texter författade av centrala ledare. ${ }^{10}$ Såtillvida är den en del av en äldre utbildningshistorisk tradition. ${ }^{11}$ Till denna tradition hör även en stor del av den historiska folkbildningsforskningen, vilken förutom organisationsfrågor främst intresserat sig för bildningsideal och programförklaringar. ${ }^{12}$ Ambitionen här är istället att ta fasta på mer verksamhetsnära praktiker och material, samtidigt som artikeln i jämförelse med tidigare forskning om kooperationen förskjuter den utbildningshistoriska analysens tyngdpunkt från frågor om konsumtion till frågor om normer för offentlig kommunikation och politik. ${ }^{13}$

Ahlbergs kritik, som KF:s propagandastudier utgick från, är ett exempel på hur reklamens och reklambranschens etablering som ekonomiskt, kulturellt och politiskt respektabelt fenomen inte var en självklarhet. En grundläggande analytisk utgångspunkt - som delas med tidigare forskning - är just att denna etablering inte bör förstås som en given följd av att kommunikationsteknikerna faktiskt fungerade, av ekonomiskt tillväxt, ökad köpkraft, etableringen av massproduktion, massdemokratins genombrott, eller något annat. Tvärtom krävdes målmedvetet arbete, vilket hittills främst studerats med fokus på branschens egna försök att vinna respekt i estetiskt, kulturellt och politiskt hänseende. ${ }^{14}$ En undersökning av KF:s studieverksamhet kan därmed bidra med en ny ingång till en sådan historisering av reklamens och propagandans samhällsroll. Kooperationen är särskilt intressant i detta sammanhang, inte bara på grund av sitt stora medlemsantal och framträdande plats i tidens

9 I forskningen dominerar frågor om organisationsformer, konsumtion och ekonomi, se exv. Hilson, Neunsinger och Patmore (2017). Bristen på forskning om kooperativ utbildningsverksamhet framhålls t.ex. av Linda Shaw, "International Perspectives on Co-operative Education," i Hidden Alternative: Co-Operative Values, Past, Present and Future, red. Anthony Webster et al. (Manchester: Manchester University Press, 2012), 59, 75; för exempel på studier av kooperativ utbildning utanför Sverige under perioden se exv. artiklar av Keith Vernon och Tom Woodin i föregående nämnda volym, samt Keith Vernon, "History, Citizenship and Co-operative Education, c. 1895-1930," i Mainstreaming Co-Operation: An Alternative for the Twenty-First Century?, red. Anthony Webster, Linda Shaw och Rachel Vorberg-Rugh (Manchester: Manchester University Press, 2016); Nicole Robertson, The Co-Operative Movement and Communities in Britain, 1914-1960: Minding Their Own Business (Routledge: London och New York, 2010), kap. 5.

10 Aléx (1994); Peder Aléx, "Gränsöverskridande samarbete: Herman Stolpe och konsumentkooperationen," i Mångsysslare och gränsöverskridare: 13 uppsatser i idéhistoria, red. Bosse Sundin och Maria Göransdotter (Umeå: Umeå universitet, 2008). Se även Harald Elldin, Klipp och bakgrunder till kooperativt fostringsarbete under ett halvsekel (Stockholm: KF, 1950).

11 Se Johannes Westberg, "Vad är utbildningshistoria?," Utbildning och demokrati 26, no. 3 (2017), $11-13$.

12 Ett viktigt undantag är Karin Nordberg, Folkhemmets röst: Radion som folkbildare 1925-1950 (Eslöv: Symposion, 1998).

13 Ett exempel på en mer lokal och praktiknära ansats i forskning om kooperativ utbildning är Robertson (2010), kap. 5.

14 Se främst Stefan Schwarzkopf, "Respectable Persuaders: The Advertising Industry and British Society, 1900-1939" (PhD diss., Birkbeck College, University of London, 2008); även exv. Stuart Ewen, PR! A Social History of Spin (New York: Basic Books, 1996); Gardeström (2018) kap. 3; Pamela E. Swett, Selling Under the Swastika: Advertising and Commercial Culture in Nazi Germany (Stanford: Stanford University Press, 2014), 31-37. 
samhällsbygge, utan mer specifikt på grund av dess särpräglade roll som både vinstdrivande marknadsaktör med egen reklamproduktion och demokratisk rörelse med folkbildande ambitioner. Kooperationen kan varken förstås som endast en ytterligare aktör på reklamfältet, jämsides med reklambyråer och branschorganisationer, eller som en renodlad folkbildningsinstitution; istället krävde dess position att frågan om propaganda och demokrati adresserades på ett sätt som förenade de till synes motsatta intressen och prioriteringar som präglade dessa båda områden.

Empiriskt utgår undersökningen för det första från Ahlbergs bok och den studiehandledning i två delar som producerades för grupperna. ${ }^{15}$ För det andra används andra studiehandledningar samt verksamhetsberättelser, småskrifter och tidskrifter publicerade av KF. ${ }^{16}$ I linje med undersökningens tre frågor kommer jag i detta material att fästa vikt vid motiveringarna av studierna, de pedagogiska övervägandena som gjordes i utformningen av dem, samt vilka kunskaper och färdigheter som var deras mål. Metoden är jämförande och kontextualiserande. Den är jämförande så till vida att KF:s hantering av dilemmat mellan effektivitet och demokratisk legitimitet väsentligen framkommer genom en närläsning av det sätt som studiehandledningarna förhöll sig till Ahlbergs framställning. Tillvägagångssättet är kontextualiserande på så sätt att propagandastudierna tolkas genom att sättas i samband med KF:s målsättningar och övriga studieverksamhet, med bredare diskussioner om reklam och propaganda samt med dåtida förståelser av demokratins utmaningar och försök att lösa dessa genom samhällstillvända bildningsverksamheter. Undersökningen utgår inte från färdiga definitioner av begrepp såsom reklam, propaganda, upplysning eller demokrati; istället är jag intresserad av hur, inom KF:s studieverksamhet, dessa och näraliggande termer gavs innebörd och sattes i bruk. I linje med en kulturteoretiskt inriktad historieforskning är jag således intresserad av hur de historiska aktörernas språk var meningsskapande och en konstituerande del i konkreta praktiker, i detta fall i form av KF:s medlemsstudier. ${ }^{17}$ Dessa studier betraktas i sin tur som interventioner i betydligt bredare samhällsdiskussioner om propaganda, reklam och demokrati. Hur gruppstudierna gick till i de enskilda fallen kan vi inte veta, men genom en läsning som tar fasta på källornas förklaringar, instruktioner, frågor och arbetsuppgifter är det möjligt att skapa en tydlig bild av studiernas pedagogiska form, de intressen och utvecklingsmöjligheter som förutsattes hos deltagarna och de förmågor som tränades.

15 Den första delen är Stolpe och Sohlenius (1935); den andra utkom först år 1936 och därefter i en något utökad upplaga 1937; hänvisningar görs här till den senare, Holter Sohlenius, Propagandafrågor: Handledning för de kooperativa gruppernas diskussioner: Avd. 4-6: Kooperativ och antikooperativ propaganda (Stockholm: KF, 1937). Första delen publicerades senare fristående som Herman Stolpe, Att tänka och diskutera: Bildning och propaganda (Stockholm: KF, 1938).

16 De senare inkluderar Kooperativa gruppen (genomgången 1929-1934) som avsåg att vara till hjälp i studierna och som ersattes av Vi vill (1934-1939), samt förbundets mer teoretiska tidskrift Kooperatören (1930-1939). Startåret motiveras av att studiehandledningarna introducerades vid denna tid, och slutåret med att kriget ställde frågor om reklam och propaganda i ett nytt läge. KF:s årliga verksamhetsberättelser har gåtts igenom för åren 1929-1939, se Kooperativa förbundets förvaltnings- och revisionsberättelser (Stockholm: KF, 1930-1940). Sökningar i KF:s arkiv vid Centrum för näringslivshistoria var resultatlösa.

17 Se exv. Anders Ekström, Representation och materialitet: Introduktioner till kulturhistorien (Nora: Nya Doxa, 2009). 


\section{Reklam och propaganda: expansion och motstånd}

Diskussionerna om reklam och propaganda i Sverige och inom KF följde ett allmänt mönster typiskt för många andra demokratier i Europa och USA under mellankrigstiden. Reklam var en expanderande bransch underbyggd av ett omfattande transnationellt utbyte av teorier, metoder, estetiska ideal och affärsmodeller. ${ }^{18}$ Likt kollegor utomlands var den svenska reklambranschens företrädare - reklammännen, som de kallade sig - under 1930-talet omvittnat entusiastiska i fråga om att inte bara konsolidera sin plats på marknader för varor och tjänster, utan även utvidga sin verksamhetssfär utöver det rent kommersiella. Reklamen "tjänar samhället" och "bygger framtiden", som två slagord uttryckte det. ${ }^{19}$ Dess tekniker kunde användas till att övertyga om i stort vad som helst - förträffligheten av en ny kaffesort, det nyttiga med mejerivaror, nya politiska program eller sociala reformer. Det var åtminstone reklammännens bild, och många utanför branschen, inte minst i politiska partier, omfamnade budskapet om den effektiva kommunikationen och dess sociala, ekonomiska och politiska fördelar. ${ }^{20}$

Andra - folkbildare, samhällsdebattörer och politiker - var måttligt imponerade av dessa anspråk. Vid sidan av estetiska och ekonomiska invändningar förekom kritik av mer politiskt slag. Denna kritik var från början av mellankrigstiden en del av en bred och omfattande internationell demokratidiskussion med fokus på såväl kommersiell som statlig och politisk propaganda, en diskussion som i Sverige framför allt tog fart på 1930-talet. Flera omständigheter sammanföll för att ge diskussionerna särskilt aktualitet och intensitet, inklusive demokratins genombrott och senare kris i Europa, tillkomsten av nya och expansionen av gamla massmedier, nya reklamtekniker och ökad konsumtion, samt erfarenheter från världskrigets propagandakampanjer. Den "allmänna opinionen" föreställdes ha en aldrig tidigare skådad betydelse vilket, i kombination med en rädsla för "massan", inte alltid sågs som något positivt. Här aktualiserades frågan om hur avvägningar skulle göras mellan effektivitet och demokratisk legitimitet i offentlig kommunikation. Hur faran med propaganda uppfattades stod på detta sätt i direkt relation till just uppfattningar om möjligheten av en kompetent demokratisk allmänhet. För dem som trodde på en sådan var reklam och propaganda ett problem då den appellerade till känslor och motverkade välunderbyggda uppfattningar om allt från konsumtionsvaror till avgörande samhällsfrågor. Mäktiga särintressen ersatte därmed allmänintresset. ${ }^{21}$ Ahlbergs bok, som KF alltså både publicerat och använde som grund för studier, är den

18 Stefan Schwarzkopf "Who Said 'Americanization'? The Case of Twentieth-Century Advertising and Mass Marketing from a British Perspective," i Decentering America, red. Jessica C. E. Gienow-Hecht (New York: Berghahn, 2007); Swett (2014), 9, 26-35.

19 Detta var parollerna för 4:e Nordiska reklamkongressen (1937) respektive tidskriften Futurum (1936).

20 Petter Tistedt, "Reklam för demokrati? Reklamens politik i mellankrigstidens Sverige," Scandia 84, no. 1 (2019), 69-75; Gardeström (2018).

21 Se exv. Hugo García, "Reluctant liars? Public debates on propaganda and democracy in twentiethcentury Britain (ca. 1914-1950)," Contemporary British History 33, no. 2 (2019); Jonathan Auerbach, Weapons of Democracy: Propaganda, Progressivism, and American Public Opinion (Baltimore: Johns Hopkins University Press, 2015); Petter Tistedt, Visioner om medborgerliga publiker: Medier och socialreformism på 1930-talet (Höör: Symposion, 2013); Tistedt 2019, 75-78; Corey Ross, "Mass Politics and the Techniques of Leadership: The Promise and Perils of Propaganda in Weimar Germany," German History 24, no. 2 (2006). 
förmodligen mest utförliga framställningen på svenska av sådan kritik. Att boken, liksom KF:s studier i propagandafrågor, hade hög aktualitet var med andra ord helt riktigt. De var en del av intensiva internationellt spridda diskussioner som KF, mot bakgrund av ambitionen att forma såväl den unga demokratin som det framväxande konsumtionssamhället, hade en särskild anledning att delta i.

\section{Ekonomisk vinst på demokratiskt vis}

KF bildades 1899 då enskilda konsumentföreningar gick samman för att tillgängliggöra goda varor till ett överkomligt pris, och senare även för att motverka monopol och karteller genom egen tillverkning. Politiskt var förbundet oberoende, i likhet med systerorganisationerna i övriga nordiska länder, även om det stod arbetarrörelsen nära. Antalet medlemmar växte stadigt. Under 1930-talet gick förbundet från omkring 450000 till knappt 670000 medlemmar, av en befolkning på drygt sex miljoner. Detta var en ansenlig framgång. KF fick både en stark röst inom den internationella kooperationen och väckte intresse i utlandet när Sveriges relativa lyckade hantering av depressionen eller dess "medelväg" mellan kapitalism och kommunism skulle förstås. ${ }^{22}$

Forskningen har visat hur omfattande, innovativ och välorganiserad kooperativ reklam kunde vara, inklusive i Sverige, där kooperationen sedan 1925 hade sin egen reklambyrå. ${ }^{23} \mathrm{KF}$ var passiv medlem i Svenska reklamförbundet från 1934 och förbundets egen Nils Willner var en respekterad reklamman. ${ }^{24}$ De annonser för egna varor och varumärken som reklambyrån producerade var centrala för KF, men därtill spreds kooperationens budskap till både medlemmar och utomstående på en mängd andra sätt: man höll möten, gav föreläsningar, ordnade fester och filmvisningar samt spred böcker, pamfletter, tidskrifter, flygblad och affischer. Även studieverksamheten räknades hit. ${ }^{25} \mathrm{I}$ fråga om den terminologi som användes av KF kunde propaganda och reklam inte bara användas som synonymer. Propaganda kunde även omtalas som upplysning, och överlappa med utbildning och uppfostran. ${ }^{26}$

KF stod alltså inte utanför reklambranschen men hade andra prioriteringar än reklambyråerna, för vilka reklamen var den primära verksamheten. I sin utåtriktade användning av reklam och propaganda liknade KF mer de politiska partierna, men kooperationen skiljde sig även från dessa genom att driva en verkligt kommersiell verksamhet. Det särskilda med kooperationen var just att den i lika mån var grundad i ekonomiska och demokratiska målsättningar: att gå med vinst och samtidigt styras enligt principen "en medlem, en röst", där medlemmarnas kunskaper om verksamheten värderades högt och ägnades omfattande omsorg. Därmed var propagandans

22 Se främst Mary Hilson, The International Co-operative Alliance and the Consumer Co-operative Movement in Northern Europe, c. 1860-1939 (Manchester: Manchester University Press, 2018); antalet medlemmar redovisades varje år i Förvaltnings- och revisionsberättelser (1930-1940).

23 Gardeström (2018), kap 5; Jonsson (2017) Schwarzkopf (2009).

24 Gardeström (2018), 131, 134.

25 Ibid., kap 5; för samtida diskussion och instruktion se t.ex. Kooperativ upplysning och utbildning: Kommittébetänkande till Kooperativa förbundets kongress år 1931 (Stockholm: KF, 1931); Anders Hedberg, Kooperativ propaganda (2:a uppl., Stockholm: KF, 1928); Harald Elldin, "Propagandans planläggning," Kooperatören 1934:12, 214-19.

26 Se exv. Harald Elldin, "Propagandans planläggning," Kooperatören 1934:12, 215-16; Gruppverksamheten: Vad den är och vill (Stockholm 1935), 4. 
löfte och problem $i$ både kommersiella som politiska hänseenden närvarande i verksamheten - det senare förstärkt av att kooperationen föreställdes endast kunna förverkliga sin potential inom ramen för demokratiska statsformer, något som utvecklingen i Europa tycktes bekräfta. ${ }^{27}$ Här krävdes aktiva överväganden som samtidigt var principiella och praktiska: hur kunde kooperationen använda en övertygande kommunikation utan att göra avkall på sina mer ideella, demokratiska åtaganden?

\section{Studier i kooperationens och demokratins tjänst}

Ambitionerna med medlemsupplysningen var höga. "Demokratin är faktiskt både i stater och fria organisationer nästan uteslutande en fråga om uppfostran av de enskilda individerna", som en ledande medlem uttryckte det i en introduktion till kooperationens idéer. ${ }^{28}$ Peder Aléx talar om KF:s "utopiska drag", där kooperationen "skulle medföra en moralisk resning för både individen och samhället". Medlemmarna skulle bli "bättre samhällsmedborgare", som "kunde ta ansvar för och styra samhället". ${ }^{29}$ Bildningsarbetets syfte var att skapa "en kunnig, rationell och moraliskt högtstående medborgare" och "en kritisk medborgaranda" vilket både skulle gynna kooperationen och samhället i stort. ${ }^{30}$ Under 1930-talet definierade sig kooperationen allt mer som en frihets- och demokratirörelse, något som i samtiden fick förklara dess, framgångar. ${ }^{31}$ Dessa strävanden var en del av en bredare samhällsreformism som tog fasta på behovet av att inte bara lära ut demokratiska ideal utan även skapa sammanhang där var och en kunde öva och tillämpa sina medborgerliga förmågor och färdigheter. Strävandena att forma en demokratisk allmänhet var här ett praktiskt arbete som satte sin prägel på de sätt som aktuella samhällsfrågor och gemensamma angelägenheter behandlades i exempelvis radion, tidningar, debattböcker och utställningar. Ambitionerna var att låta medborgarna sakligt informera sig, reflektera, ta ställning, utbyta åsikter och förstå det egna livet i större sociala, ekonomiska och politiska sammanhang. ${ }^{32}$

KF:s demokratiska ideal överlappade även med de som präglade folkbildningsarbetet i stort, så som det exempelvis bedrevs i Arbetarnas bildningsförbund ( $\mathrm{ABF}$ ), som KF också var anslutet till. Även i fråga om ämnesval samt pedagogiska metoder låg KF nära särskilt arbetarrörelsens folkbildning, med sin starka betoning på arbete i studiecirklar, vilka inom KF alltså kallades grupper. Liksom i denna folkbildning lade KF stor vikt vid såväl deltagarnas egen aktivitet som ett ömsesidigt utbyte i det kollektiv gruppen utgjorde. Det var en aktivitet och ett utbyte som skulle göra demokratin möjlig genom att höja folket moraliskt och intellektuellt. Demokratin förstods då inte endast som en form för politisk representation på nationell nivå, utan även som sätt att hantera gemensamma angelägenheter och organisera samhällslivet

27 Se exv. Anders Örne, Demokrati (Stockholm: KF, 1931), 9; Herman Stolpe, "Demokratins kris," Kooperatören 1933:20; Herman Stolpe, Handledning för de kooperativa gruppernas diskussioner: Kooperation - demokrati - diktatur (Stockholm: KF, 1938).

28 Anders Örne, Kooperativa ideer och spörsmål (2. uppl., Stockholm: KF, 1936), 158-59; se även t.ex. Herman Stolpe, "Kuggar eller medarbetare," Kooperatören 1936:18, 401.

29 Aléx (1994), 16.

30 Ibid., 76, 78. Se även Elldin (1950), 272. Om motsvarande målsättningar utomlands, se Vernon (2016); Robertson (2010), kap. 5.

31 Aléx (1994), 118.

32 Tistedt (2013). 
i bredare mening. För detta arbete erbjöd folkbildningen praktisk övning. ${ }^{33}$ Kooperatörerna benämnde också själva ibland gruppstudierna som just folkbildning, även om detta inte uttömde deras uppgift. ${ }^{34}$

I jämförelse med annan folkbildande verksamhet var KF däremot särpräglad i relationen till staten. Att staten varit en viktig förutsättning för mycket folkbildningsverksamhet är välkänt, och det var till och med denna relation till staten som i hög grad gav folkbildningsbegreppet sin betydelse. ${ }^{35} \mathrm{Men} \mathrm{KF}$ avstod från statligt stöd och tillät exempelvis inte de egna grupperna att anmäla sig som ABF-cirklar. Att KF ekonomiskt skulle stå på egna ben var en central princip, men eftersom studierna delvis syftade till att lära deltagarna sprida kooperationens budskap - att själva göra propaganda - var de inte heller berättigade till statligt eller kommunalt stöd. ${ }^{36}$ Då gruppernas uppgifter förklarades i tidskrifter och broschyrer påmindes ofta om att de avsåg att vara både studiecirklar och kommittéer eller organ för propaganda. En introduktion till gruppverksamheten förklarade:"En grupp är helt enkelt en sammanslutning av intresserade föreningsmedlemmar, förtroendemän och anställda, som tagit till sin uppgift att fördjupa sina insikter i kooperativa spörsmål genom studier, och att göra dessa studier fruktbringande i propaganda för föreningen bland medlemmarna och allmänheten." ${ }^{37}$ Det är typiskt för tidens terminologi att denna propaganda även kunde omtalas som ett "upplysningsarbete", eller i något fall till och med som "folkbildningsarbete" eller "missionerande".38

När handledningen om propaganda publicerades hade upplysning och studier länge varit en central del i kooperationens verksamhet. Dess mönsterstadgar för ingående föreningar från 1908 stipulerade att 2,5 \% av vinsten skulle användas till upplysningsarbete, och 1918 inrättades en central studieavdelning. Ett par år senare togs initiativet till gruppstudierna, och därtill kom kurser på den egna kursgården Vår gård samt korrespondensundervisning. Tillsammans med den kooperativa pressen, bokutgivningen och medlemsupplysningen i de särskilda kvinnogillena utgjorde detta kärnan i KF:s studieverksamhet. ${ }^{39}$ Antalet grupper och medlemmar ökade stadigt under 1930-talet: från något hundratal grupper i början av decenniet till drygt 2700 med över 34000 deltagare

33 Se främst Samuel Edquist, "Studiecirkeln - en demokratisk revolution?," i Utbildningens revolutioner: Till studiet av utbildningshistorisk förändring, red. Anne Berg et al. (Uppsala: Uppsala Studies of History and Education, 2017) samt Per Sundgren, Kulturen och arbetarrörelsen: Kulturpolitiska strävanden från August Palm till Tage Erlander (Stockholm: Carlssons, 2007) särskilt kap. 2. KF hörde till de medlemmar av $\mathrm{ABF}$ som organiserade studier helt på egen hand.

34 Se exv. A. G-s., "Grupperna och A. B. F.," Kooperativa gruppen 1931:38; Holter Sohlenius, "Mellan fyra ögon talar man ut," Vi vill 1935:9 upplaga A, 6; jfr även Herman Stolpe, "Studieplaner och cirkelarbete," Bokstugan 1934:1.

35 Samuel Edquist, "Demarcating Popular Education with Government Subsidies: Sweden 19111991," Nordic Journal of Educational History 2, no. 1 (2015); relationen till staten är även ett tema i Popular Education, Power and Democracy Swedish Experiences and Contributions, red. Ann-Marie Laginder, Henrik Nordvall och Jim Crowther (Leicester: Niace, 2013).

36 Olof Ruin, Kooperativa förbundet 1899-1929: En organisationsstudie (Stockholm: Rabén \& Sjögren, 1960), 344-345; se även G-s., "Grupperna och A.B.F.," Kooperativa gruppen 1931:38; Herman Stolpe, "Gruppverksamheten," Bokstugan 1936:5, 162.

37 Gruppverksamheten (1935), 3 (citatet), 4; se även t.ex. "Gör tanken fri!," Vi vill 1935:2 upplaga A, 6; Hedberg (1928), 18-19.

38 Gruppverksamheten (1935), 4; Holter Sohlenius, "Mellan fyra ögon talar man ut," Vi vill 1935:9 upplaga A, 6; Hedberg (1928), 24.

39 Aléx (1994), 73-89; om det tidiga grupparbetet även Herman Stolpe, Stark demokrati genom ökade kunskaper: Medlemsupplysningen inom den svenska kooperationen (Stockholm: KF, 1939), 13-16. Se även Förvaltnings- och revisionsberättelser (1930-1940), avdelningen om organisationsavdelningen. 
under studiesäsongen 1938-1939. ${ }^{40}$ Under årtiondets sista år genomfördes medlemsundersökningar som pekade på ett ökande deltagande av kvinnor, från en tredjedel 1937 till $43 \%$ under $1939 .^{41}$

Ökningen av antalet deltagare i grupperna sammanföll inte bara med en påtaglig medlemstillströmning i stort utan även med att studiehandledningarna introducerades 1929 och succesivt utökades med allt fler ämnen. ${ }^{42}$ Handledningarna var avsedda att lösa svårigheten med att hitta personer som kunde leda grupperna, men de fick också ett pedagogiskt syfte i och med att gruppverksamheten gjordes mer jämlik och kunde anta karaktären av otvungen diskussion. Ingen lärare satt inne med svaren. På sin höjd kunde grupperna använda sig av en inledare, vars uppgift var att uppmuntra till diskussion, särskilt om de mer principiella frågorna. Handledningarna gav noggranna läsanvisningar till en eller flera kursböcker samt frågor att diskutera under gruppernas arbete, vilket som regel förutsattes bli uppdelat på minst tre möten. Handledningarna sades vara avsedda att stimulera till diskussion och ett gemensamt sökande efter de bästa svaren, utan att några tydliga rätt eller fel stipulerades. För vissa frågor uppmuntrades grupperna att skriva ner sina svar och skicka in till granskning av personalen på studieavdelningen, men inte heller denna granskning avsåg att ge definitiva svar utan syftade mer till att få grupperna att fördjupa och utveckla sina resonemang. Denna kontakt mellan grupperna och studieavdelningen gav den senare en möjlighet att inte bara få en uppfattning om hur många grupperna var utan även se hur deras arbete fungerade. ${ }^{43}$ Sådan återkoppling värderades högt. ${ }^{44}$ Det var också efter förfrågan från grupperna som handledningen om propagandafrågor utarbetats. ${ }^{45}$

Studiehandledningen i propagandafrågor - avsedd för sammanlagt minst sex möten - följde detta allmänna mönster. Författarna till handledningen var Holter Sohlenius samt Herman Stolpe, vilka båda utmärkte sig för sitt intresse för både pedagogik och propaganda. Den senare var långvarig studierektor för gruppverksamheten och betonade starkt dialog, fördomsfritt och antiauktoritärt kunskapssökande, tanke- och erfarenhetsutbyte. ${ }^{46}$ Det var ett ideal som låg nära Alf Ahlbergs, som själv slog fast att en "verklig diskussion borde vara ett samarbete, icke en meningskamp" och att studiecirkeln var ett exempel på en sådan studieform. ${ }^{47}$

40 Siffrorna redovisades i Förvaltnings- och revisionsberättelser (1930-1940), avdelningen om organisationsavdelningen.

41 Förvaltnings- och revisionsberättelser (1938), 56; (1939), 58; (1940), 61.

421939 fanns 29 studieämnen att välja på, se Förvaltnings- och revisionsberättelser (1940), 61. Ekonomiska frågor dominerade men även handlingar om familjefrågor, hemarbete, bostäder, hälsa, internationell fred, ungdomens roll och mer allmänna framställningar av kooperationens idéer framställdes. Till sitt ämne avvek således handledningen i propagandafrågor från de övriga.

43 Se framför allt "En betydelsefull nyhet för grupperna," Kooperativa gruppen 1929:25; Gruppverksamheten (1935); Herman Stolpe, "Gruppverksamheten," Bokstugan 1936:5; "Gruppledarskapets problem," Vi vill 1937:6 upplaga A; Stolpe och Sohlenius (1935), 1-3.

44 Gruppernas arbete diskuterades även vid ledarkurser och möten mellan studieledningen och gruppernas ledare, se exv. Förvaltnings- och revisionsberättelser (1936), 44; "Handledningarnas användning," Kooperativa gruppen 1932:46 och 1932:47; "Praktiska diskussionsmetoder," Kooperativa gruppen 1933:56; se även "Handledningarna äro goda vägvisare," Kooperativa gruppen 1932:40; "Belåtna gruppledare," Kooperativa gruppen 1933:53; Stolpe och Sohlenius (1935), 28.

45 "Gör tanken fri!," Vi vill 1935:2 upplaga A, 6.

46 Aléx (2008).

47 Ahlberg (1934), 174-175, citatet 174. 
Ahlberg, vars Tankelivets frigörelse alltså fick tjänstgöra som ensam kursbok för gruppstudierna i propagandafrågor, var en flitig och populär skribent samt i flera decennier verksam som lärare och rektor vid arbetarrörelsens folkhögskola i Brunnsvik. Någon konventionell socialist eller socialdemokrat var han däremot inte, därtill var han alltför kritisk mot idén om klasskamp, alltför fäst vid eviga värden, gudstro och personlighetsutveckling och inte tillräckligt intresserad av praktiska frågor om yrkesliv, vardag och politisk organisering. ${ }^{48}$ Tankelivets frigörelse samlade upp många av de ämnen Ahlbergs gjort sig känd för att intressera sig för - samhällskunskap, filosofi, psykologi och bildning - och ramade in dem som en fråga om demokratins möjligheter i "massornas tidsålder", eller med andra ord en tid då massorna visserligen inte själva styrde, men då varje makt måste stödja sig på "massor och massopinioner". ${ }^{49}$ Boken blev något av en folkbildningsklassiker, med nya utgåvor ända till 1980-talet och flera översättningar. ${ }^{50}$ Att han valde propaganda, åsiktsbildning och offentlig kommunikation som en väg in i frågan gjorde att boken kunde tas som utgångspunkt i Sohlenius och Stolpes arbete med KF:s egna "propagandafrågor". Vilka var då Ahlbergs viktigaste argument, och hur kunde hans bok användas av kooperationen?

\section{Tankelivets frigörelse från propaganda}

Det Ahlberg kallade en "verkligt 'upplyst' demokrati" krävde "självständigt tänkande människor, icke blinda redskap för den sociala suggestionen". Därför var "demokratins öde i världen oskiljaktigt förenat med frågan, om den formella tankefriheten kan omvandlas till verklig positiv tankefrihet. Samhällslivets frigörelse kräver tankelivets frigörelse." ${ }^{11}$ Bokens uppgift var att "röja upp i de vildsnår av vanetänkande, fras- och slagordstänkande, vulgärt masstänkande och känslotänkande, sociala fördomar och vidskepelser, som hota att växa över nutidslivet" ${ }^{52}$ De fyra första kapitlen efter inledningen diskuterade människors förställningar om verkligheten, hur dessa blev till och vad som stod i vägen för att tänkandet skulle vara fritt, så att även samhällslivet kunde vara det. Det handlade om rationalisering, att människor söker efter fakta för att bekräfta det de redan tror på; om svårigheterna att konstatera fakta på grund av brister i perception och minne; om feltänkande som uppstår eftersom människor alltid i någon mening är subjektiva; och det handlade om fördomar på grund av grupptillhörighet i vad Ahlberg kallade ras, nation, klass, yrke, religion och kön. ${ }^{53}$

Framställningen byggde upp för det femte kapitlet som förklarade de problem som kom sig av att människans psykologiska svagheter kunde vändas emot dem i ett modernt samhälle. "Propaganda, agitation och reklam", skrev Ahlberg, "äro olika nyanser av en och samma metod, den sociala suggestionens metod. Alla tre formerna ha en egenskap gemensam: det gäller för dem icke att bevisa utan att övertyga." ${ }^{4}$ Här

\footnotetext{
48 Kjell Krantz, Alf Ahlberg: En biografi (Ludvika: Dualis, 1998).

49 Ahlberg (1934), 15.

50 Förvaltnings- och revisionsberättelser (1937), 65, redovisar sex upplagor om sammanlagt 9000 exemplar. Den femtonde och sista upplagan publicerades 1986.

51 Ahlberg (1934), 25-26.

52 Ibid., 26.

53 Ibid., kap I-IV.

54 Ibid., 125
} 
motiverades den föregående diskussionen om psykologiska svagheter: propaganda, agitation och reklam "arbeta icke efter logiska utan efter psykologiska lagar. Och därvid göra de bruk av alla de svagheter och felkällor, som vidlåta vårt tänkande. Ja, man kan utan större överdrift påstå, att de leva av dem." ${ }^{55}$ Det var tekniker som utnyttjades av regeringar, politiska partier, kyrkor och sekter, och ekonomiska intressenter. ${ }^{56}$ Ahlberg förklarade här sin uppfattning om den kommersiella reklamen och dess fundamentala närhet till politikens metoder:

\begin{abstract}
Man kan sända ut i marknaden en och samma vara i olika förpackningar och till olika priser. Det parti, som har en mera suggestiv bild på förpackningarna, ett mera suggestivt namn, som reklameras för på ett effektivare sätt, blir livligare efterfrågat, t. o. m. om det skulle råka vara dyrare. Framgången bevisar ingenting om kvaliteten. Detsamma gäller nu även om opinionsbildningarna. ${ }^{57}$
\end{abstract}

Resultatet var, enligt Ahlberg, att åtminstone de åsikter nutidsmänniskan omfattar i sociala sammanhang inte var bildade genom "egen eftertanke över frågorna, genom ett samvetsgrant och kritiskt studium av fakta, genom omsorgsfullt väga skäl och motskäl mot varandra", utan istället var de till allra största delen "framsuggererade". ${ }^{58}$ I det politiska livet var det inte de mest förnuftiga, vederhäftiga eller välgrundade meningarna som avgick med segern, utan de "som propageras med de bästa resurserna, på det skickligaste, efter publikens allmänna mentalitet bäst avpassade sättet." ${ }^{59}$ Riskerna med detta kunde samtidshistorien visa:

\begin{abstract}
Diktaturstaterna äro tills vidare det största världshistoriska exemplet på det politiska tänkandets förfall genom propagandaapparatens effektivisering. I Tyskland har man formligen med en störtflod av propaganda på ett par år lyckats idiotisera en upplyst kulturnation [...] Meningar, som ännu för några år sedan skulle mötts med ett allmänt gapskratt, äro nu allmänna opinioner, ja vetenskapligt fastslagna sanningar vid universitet och högskolor. ${ }^{60}$
\end{abstract}

Frågan om vilka åtgärder som kunde vidtas för att göra människor mindre mottagliga för propaganda besvarade Ahlberg på flera sätt. Det krävdes en bättre ekonomi, eftersom det "vore oresonligt att begära ett klart och kritiskt objektivt tänkande, när magen är tom"; det krävdes att yttrandefriheten hölls vid liv, att partsinlagor inte gavs sken av objektivitet, och att den intellektuella nivån på pressens medarbetare höjdes. ${ }^{61}$ Det krävdes dessutom att "den sociala suggestionsapparaten och dess verkningssätt" avslöjades så att människorna skulle kunna genomskåda den. ${ }^{62}$ Till sist krävdes ett mer allmänt bildningsarbete, eftersom "suggestibiliteten under normala förhållanden avtar med vanan vid intellektuell verksamhet, ty med denna följer ut-

\author{
55 Ibid. \\ 56 Ibid., 126. \\ 57 Ibid., 125. \\ 58 Ibid., 126. \\ 59 Ibid., 128. \\ 60 Ibid., 129. \\ 61 Ibid., 137 (citatet), 138. \\ 62 Ibid., 138.
}


bildningen av ett kritiskt sinnelag." ${ }^{33}$ Till detta bildande och avslöjande arbete avsåg Ahlbergs bok att bidra.

\section{Gruppverksamhetens pedagogik}

Att det gick att förhålla sig på olika sätt till Ahlbergs bok var tydligt. I kooperationens tidskrifter kunde den lyftas fram som en "insats i det andliga saneringsarbetets tjänst", men också som "ett hjälpmedel för våra propagandister att kritiskt komma till rätta med våra motståndares argument”. ${ }^{64}$ Dessa två förhållningssätt uteslöt inte nödvändigtvis varandra, men inställningen till den moderna reklam som Ahlberg diskuterade var verkligen splittrad inom KF. Kritik av "den moderna försäljningspropagandan" och det sätt den vilseförde kunder - särskilt husmödrar - samsades med både en omfattande reklamproduktion och resonerande försvar av densamma. ${ }^{65}$ Handledningen i propagandafrågor var producerad mot bakgrund av att det inte var självklart för KF:s medlemmar om och hur effektiv propaganda och demokratiska ideal kunde förenas.

Valet att låta studiehandledningen i första hand tala om propaganda snarare än reklam handlade om en skillnad i tonvikt mellan dessa termer som - även om de som regel tillläts peka ut samma typ av metoder - var tydlig i KF:s användning av dem. Medan reklam primärt avsåg kommersiell verksamhet var propaganda ett bredare begrepp som kunde omfatta kommersiell reklam men även innefattade mer renodlat ideella syften, såsom att övertyga både medlemmar och utomstående om kooperationens förträfflighet. ${ }^{66}$ Det senare var som bekant ett av gruppernas syften, vilket innebar att handledningen i propagandafrågor gav ett slags metaperspektiv på gruppernas verksamhet. Det är tydligt från KF:s tidskrifter att man inom ledande håll var väl medvetna om medlemmarnas olika grad av engagemang och involvering, och studierna i propagandafrågor riktades särskilt om än inte exklusivt till dem som hade för avsikt att bidra till propagandaarbetet. ${ }^{67}$

Ahlbergs bok handlade inte specifikt om KF:s upplysning eller propaganda. Men handledningen placerade in den i ett sådan sammanhang, så att även Ahlbergs mer abstrakta resonemang och hans exempel från politiken gjordes relevanta för kooperationens medlemmar. Detta var i själva verket en fundamental del av pedagogiken: den lästa litteraturen och de stora samhällsfrågorna skulle förankras i studiedeltagarnas egna erfarenheter som samhällsmedborgare och medlemmar av kooperationen. ${ }^{68}$

Uppgiften för KF:s handledningar var att ge en röd tråd till läsningen av litteraturen samt att ställa frågor. ${ }^{69}$ Detta kunde gå till på olika sätt. I den första delen av handledningen i propagandafrågor följde upplägget helt Ahlbergs bok som lästes och diskuterades kapitel för kapitel, medan den andra byggde vidare på föregående

63 Ahlberg (1934), 140.

64 Sven G Strand, "Tankelivets frigörelse," Kooperatören 1935:8, 157; "Våra hjälpmedel: Flera nya handledningar till hösten," Vi vill 1935:6 upplaga A, 6.

65 Citatet i Thorsten Odhe: "Konsumenternas fria val," Kooperatören 1932:20, 383; se vidare t.ex. Gertrud Bergström, "Den moderna reklamen och husmödrarna," Kooperatören 1930:17; Anders Örne, De sju grundsatserna: Kooperationens program i kort sammanfattning. (6. uppl., Stockholm: KF, 1932), 12; Nils Willner, "Kooperation och reklam," Kooperatören 1930:23-24.

66 Gardeström (2018), kap 5.

67 Se t.ex. Holter Sohlenius, "Medlemsintresset - några erfarenheter från föreningskurser," Kooperatören 1935:14; "Modern propaganda," Vi vill 1937:11.

68 Detta gällde även i KF:s studieverksamhet mer allmänt, se Aléx (1993), 82.

69 Herman Stolpe, "Studieplaner och cirkelarbete," Bokstugan 1934:1, 25. 
insikter men förhöll sig friare till boken. Handledningarnas diskussionsfrågor var också av olika slag. Vissa frågor testade främst förståelsen av Ahlbergs bok eller efterfrågade egna exempel på sådant som den diskuterade..$^{70}$ På andra frågor gavs svaren redan av handledningarna, eller så var det åtminstone inte svårt att lista ut hur det var tänkt att man skulle besvara dem. ${ }^{71}$ Men många frågor saknade färdiga eller givna svar. Dessa krävde mer egen reflektion och artikulering av egna uppfattning$\mathrm{ar}^{72}$ Som Herman Stolpe förklarade fick inte handledningarna "slaviskt" följa litteraturen, utan kunde gå utanför den för att "ställa gruppdeltagarnas förmåga att tänka självständigt på prov." ${ }^{\text {"73 }}$ Detta var en central aspekt av det Stolpe kallade "demokratin icke blott som fras utan som reell arbetsform".74

Till det som ändå accepterades utan problematisering hörde Ahlbergs psykologi. I handledningens andra del togs denna till utgångspunkt för diskussioner om varför många konsumenter inte anslutit sig till kooperationen eller till och med var direkt fientligt inställda till den, samt hur detta motstånd kunde bemötas. Möjligheten att det skulle kunna ligga något $i$ invändningarna mot kooperationen togs inte upp till allvarlig prövning, men handledningen påtalade också att inte heller det positiva som sades om kooperationen skulle accepteras utan vidare. ${ }^{75}$ Samtidigt riktades de psykologiska insikterna även mot kooperationens medlemmar, inklusive deltagarna i gruppstudierna. Handledningen frågande: "Hur har vi fått våra åsikter om kooperationen?"76 Detta följdes upp med vardagliga exempel och frågor om egna erfarenheter. Var det genom läsning av kooperationens program, genom att ha handlat $\mathrm{i}$ dess affärer eller i diskussioner med medlemmar som de egna åsikterna bildats? ${ }^{77}$

Dessa övningar i självreflektion gavs lika stor plats som reflektionen kring kooperationens motståndare, och samma psykologi kunde förklara både egna och andras åsikter. Poängen var, uppenbarligen, för det första att förstå och motverka hindren för kooperationens fortsatta framgång och medlemsrekrytering. För det andra kunde självrannsakan leda fram till en mer saklig och därmed starkare grund för det egna stödet till kooperationen. Användningen av Ahlbergs psykologi stod därmed helt i kooperationens tjänst på ett öppet instrumentellt och egennyttigt sätt. Men den lärde samtidigt ut en principiellt icke-chauvinistisk inställning till åsiktsbildning: vi som är med är inte bättre än de som inte är med och vårt stöd till kooperationen kan vara lika irrationellt grundat som andras motstånd. ${ }^{78}$

Gruppstudierna var utformade för att deltagarna skulle hitta sätt att ersätta egna ofta irrationella och subjektiva åsikter om kooperationen med sådana som istället var objektiva - grundade i nyktert konstaterade fakta - och tekniken för detta var att tillsammans uppenbara och artikulera känslotänkanden, godtyckliga och ytliga slut-

70 T.ex. Stolpe och Sohlenius (1935), 4, 30; Sohlenius (1937), 16, 50.

71 T.ex. Stolpe och Sohlenius (1935), 28, 32; Sohlenius (1937), 8, 36.

72 T.ex. Stolpe och Sohlenius (1935), 14, 36; Sohlenius (1937), 10, 16; se även "Gruppledarskapets problem," Vi vill 1937:6 upplaga A, 2.

73 Herman Stolpe, "Gruppverksamheten," Bokstugan 1936:5, 164-65.

74 Ibid.

75 Sohlenius (1937), exv. 34.

76 Ibid., 24; även exv. Stolpe och Sohlenius (1935), 1, 28.

77 Sohlenius (1937), 24-34.

78 Ibid., 20. 
satser och oprövade antaganden. Åsikterna om kooperationen kunde ges en mycket stabilare grund genom egna undersökningar (till exempel jämförelser av varor och priser), genom litteraturstudier och genom att möta opposition i diskussion. ${ }^{79}$ Det senare var avgörande och överlappade därtill med vad som lanserades som det mest effektiva sättet att övertyga om kooperationens förträfflighet, nämligen "personlig propaganda". Den gick just ut på att inte föreläsa utan att diskutera och ställa frågor, så att motståndarna mötte opposition och själva uppenbarade och artikulerade sin egen okunskap och därmed lärde sig något nytt. ${ }^{80}$ Gruppstudierna innehöll dock även en hel del metareflektion kring upplysning, diskussion och propaganda. Även gruppstudierna och handledningen själv skulle diskuteras kritiskt. ${ }^{81}$

\section{Legitim och användbar propaganda}

Samtidigt som mycket i Ahlbergs bok accepterades och sattes i bruk i kooperationens tjänst så fanns avgörande skillnader. Propaganda och reklam var alltid något dåligt för Ahlberg - det var alltid suggererade tekniker som utnyttjade psykologiska svagheter, förgiftade tankelivet och stod i motsats till rationell diskussion. Ett sådan förståelse kunde inte kooperationen överta om man samtidigt ville göra egen propaganda och hävda demokratiska och medborgerliga normer. Det betydde i praktiken att man försköt betydelsen av ordet propaganda, så att det inte nödvändigtvis likställdes med en illegitim suggestion. Propaganda var helt enkelt alla försök att påverka handlande och att förändra åsikter var ett medel för detta mål. Det kunde göras på bra och dåliga sätt. "Frestelsen att i propagandan bibringa folk falska åsikter kan [...] vara ganska stor", slogs inledningsvis fast i handledningens andra del. "Syftet är ju inte att meddela fakta, utan att påverka människors handlingssätt. Propagandan kan alltså lätt komma att missbrukas."

Propaganda, inklusive kommersiell reklam, var acceptabel om den tjänade ett gott syfte och var sanningsenlig. Men hur kunde man lita på att kooperationens propaganda var sanningsenlig? Holter Sohlenius utvecklade detta i en artikel som gruppdeltagarna rekommenderades att läsa. Han skrev att "om [...] de, som fătt i uppdrag att leda propagandaarbetet ha samma intressen som uppdragsgivarna, och dessa senare äro just de, som propagandan vänder sig till, föreligger inte denna risk [att sanningen kommer i andra rummet]. Här träder intresset för fakta och sanning $i$ förgrunden." ${ }^{83}$ Eller som det stod i handledningen: "Vi ha [...] inga andra än oss själva att lura med en falsk förkunnelse." ${ }^{84}$ Det var med andra ord kooperationens särskilda organisationsform som gjorde dess propaganda pålitlig. Kooperationen hade till skillnad från andra aktörer inga incitament till att tala osanning. Så såg handledningens grundläggande legitimering av propaganda ut - den kunde tjäna ett gott syfte och vara sanningsenlig, och att kooperationens propaganda levde upp till detta garanterades av dess demokratiska organisation.

79 Ibid., 28-32; se även "Gör tanken fri!," Vi vill 1935:2 upplaga A.

80 Sohlenius (1937), 44-50; se även Holter Sohlenius, "Mellan fyra ögon talar man ut," Vi vill 1935:9 upplaga A; Holter Sohlenius, "Propagandaövningar vid gruppmötena," Vi vill 1936:9 upplaga A.

81 Sohlenius (1937), 42; Stolpe och Sohlenius (1935), 36-40; se även not 42.

82 Sohlenius (1937), 2, 4. Denna förklaring lades till i handledningens andra upplaga.

83 Holter Sohlenius, "Propaganda och sanning," Kooperatören 1935:11, 235; Sohlenius (1937), 6.

84 Sohlenius (1937), 54. 
Men ett särskilt problem återstod: slagord. Här går det inte att säga att Ahlberg och kooperationens handledning talade om olika saker genom att definiera orden på olika sätt. När det gällde språkets makt över tanken - vilket var en källa till de "vanliga tankefel" som Ahlberg diskuterade - måste man vara särskilt på sin vakt mot slagorden, slog både Ahlberg och handledningen fast. ${ }^{85}$ När handledningen i propagandafrågor lanserades hade det talats om en "front mot slagordstänkandet". 86 Men som handledningen också noterade använde sig kooperationen själv av slagord, vilket man kunde invända mot. Borde man verkligen "vänja folk vid slagordstänkande"? ${ }^{87} \mathrm{KF}$ använde främst slagord i kommersiell reklam, men slagorden var också en form av propaganda som särskilt associerades med politik. KF:s ledande teoretiker Anders Örne kopplade exempelvis slagorden direkt till hur "den demokratiska styrelseformen gjort bankrutt" i stater där folken inte varit vana vid självstyrelse. ${ }^{88}$

Så hur kunde slagord legitimeras? Handledningens lösning på detta var att även om de verkade genom suggestion så var kooperationens slagord användbara och legitima, inte för att de åtföljdes av argument och hållbara motiveringar (det gjorde de inte) utan för att de kunde förses med sådana. De var sanna även om det inte gick att avgöra för publikerna. Slagorden fick "tjäna som en första impuls till eftertanke, en väckare till fundering över kooperationen. Sedan stå ju flera vägar öppna för dem, som genom slagorden börjat fundera, att tränga djupare in i de kooperativa idéerna och själva övertyga sig om slagordens riktighet." ${ }^{\prime 9}$ En sådan legitimering av slagord kunde inte accepteras utifrån Ahlbergs synsätt. För Ahlberg var den viktiga frågan inte om propagandan var sann utan det faktum att den suggererade sina publiker, att den utnyttjade psykologiska svagheter istället för argument, bevis och diskussion. Även om de åsikter eller idéer som uttrycktes i propagandan var sanna - vilket de mycket väl kunde vara - så var den ett problem för ett demokratiskt samhälle som behövde tankefrihet för att fungera.

\section{Demokratin och tilltron till folket}

På ett sätt - i sin kritik av reklam och propaganda - var Ahlberg mer radikal än kooperationen. För honom var slagord oacceptabla eftersom de övertygade genom suggestion, inte argument. Ahlberg ställde höga krav på offentlig kommunikation för att den skulle vara legitim i ett samhälle med full tankefrihet. Men Ahlberg var samtidigt mer elitistisk än kooperationen - hans demokratiska ideal, tvärt emot vad man skulle kunna tänka sig, var mer begränsade. Detta inkluderade folkbildningens uppgifter. Han framhöll således att "[v]ad folkbildningen i främsta rummet måste åstadkomma är [...] att inge människor en känsla för det egna vetandets och kunnandets begränsning och lära dem välja de kvalificerade ledarna." ${ }^{90}$ Detta definierade för Ahlberg medborgarnas uppgift i en "upplyst demokrati".91

85 Ahlberg (1934), kap VI, om slagord särskilt 148; Stolpe och Sohlenius (1935), 34.

86 "Gör tanken fri!," Vi vill 1935:2 upplaga A, 6.

87 Sohlenius (1937), 52.

88 Anders Örne, Kooperativa ideer och spörsmål (2. uppl., Stockholm: KF, 1936), 158; se även "En ny annonsstil? Affärsekonomis första bordssamtal med 6 reklammän," Affärsekonomi 1935:17, 887; Gardeström (2018), 154.

89 Sohlenius (1937), 52, 54.

90 Ahlberg (1934), 141.

91 Ibid., 23. Även andra folkbildare framförde liknande argument, se Edquist (2017), 154. 
Kooperationens demokratiska normer var mer ambitiösa - både när det gällde dess egen verksamhet, som byggde på att medlemmar deltog på ett mer omfattande sätt än att endast utse och sedan följa de bästa ledarna, och när det gällde samhällslivet i stort. Stolpe, studieavdelningens rektor, var helt överens med Örne då den senare skrev att det som kännetecknade demokratin var att folket, "för vilka samhället är till", inte bara hade rättighet att "medverka vid tillkomsten av sin styrelse" utan även att "fastställa reglerna för dess verksamhet, kontrollera, att dessa regler följas och att makten utövas i det helas intresse, samt möjlighet att avlägsna en styrelse, som icke längre tillfredsställer folkflertalets krav i fråga om de allmänna riktlinjerna för maktutövningen." ${ }^{92} \mathrm{KF}: s$ gruppstudieverksamhet byggde - liksom annan folkbildning och försök att engagera allmänheten i gemensamma angelägenheter - på antagandet att folk tillsammans kunde begripa och bilda kvalificerade uppfattningar i ganska svåra frågor om ekonomi, politik och samhällsliv. ${ }^{93}$ Experter behövdes och vissa saker, som att bygga broar, kunde lämnas över till dem. Men handledningen fortsatte resonemanget med att ställa ett par ledande frågor: "Är det emellertid berättigat att göra en direkt jämförelse mellan tekniska fackuppgifter (t. ex. brobygge) och samhällsbyggandets uppgifter? Kan man bygga ett samhälle efter samma principer som en bro? ${ }^{94}$ Detta var i direkt kontrast till Ahlberg, som inte gjorde någon sådan klar distinktion. ${ }^{95}$

Tilliten till "folket" i folk-bildningen var således större hos kooperationen än hos Ahlberg. Viss form av propaganda var inte så farlig som Ahlberg ville göra gällande, utan kunde tvärtom tjäna ett gott syfte. Det var något som kommunicerades till gruppdeltagarna inte bara genom studiehandledningarnas budskap utan även genom den form för lärande som de uppmuntrade till - förankrat i diskussion och egna vardagliga erfarenheter. I jämförelse var Ahlbergs bok monologisk och en aning mästrande. Men dess budskap kunde vändas emot den själv, eller som handledningen slog fast: "Ahlbergs bok har just till uppgift att lära oss tänka fritt och vi skulle svika hans boks syfte, om vi utan vidare accepterade allt, vad som där säges, utan att vi först prövat det i våra egna erfarenheters ljus." ${ }^{\text {96 }}$ Ett sådant kritiskt tänkande, förankrat i erfarenheter och i diskussion, kunde alltså öppna för en acceptans för propaganda, även av ett mer suggererande slag.

Kooperationens kritik av viss form av propaganda och reklam liknade i hög grad sådan som framfördes i etablerade reklamkretsar - och det är värt att påminna om att även om reklam inte var kooperationens kärnverksamhet så var den en del av etableringen av mellankrigstidens reklambransch. Liksom mer renodlade företrädare för den branschen hävdade kooperatörer i studiehandledningarna och tidskrifter att det fanns reklam som var sanningsenlig och att annan reklam var en oönskad avart. ${ }^{97}$ Att göra skillnad på sann och osann reklam och propaganda, och att omfamna

92 Örne (1931), 15; Herman Stolpe, "Demokratins framtid och värde," Kooperatören 1931:18, 316.

93 Se vidare Tistedt (2013).

94 Stolpe och Sohlenius (1935), 6, 8.

95 Jfr särskilt Ahlberg (1934), 19-24.

96 Stolpe och Sohlenius (1935), 4.

97 Se t.ex Stolpe och Sohlenius (1935), 1; Sohlenius (1937), 50-54; Gertrud Bergström, "Den moderna reklamen och husmödrarna," Kooperatören 1930:17; Thorsten Odhe: "Konsumenternas fria val," Kooperatören 1932:20; Holter Sohlenius, "Propaganda och sanning," Kooperatören 1935:11. 
den förra, var alltså inte originellt. Det intressanta i detta fall är snarare hur det gjordes och lärdes ut. När reklammännen höll kongress i Stockholm med slagordet "reklamen tjänar samhället" som ledstjärna så var det egennyttiga föga svårtolkat: det var reklam för reklamen, och var man avogt inställd till reklam så kunde man vara det även till arrangemang av detta slag. ${ }^{98}$ Kooperationen ställde däremot sina studieintresserade medlemmar inför uppgiften att själva upptäcka, diskutera och pröva gränserna mellan acceptabel och oacceptabel propaganda. ${ }^{99}$ Därmed var denna distinktion inte endast något som reklammännen själva påstod fanns där, utan den förankrades i egen erfarenhet och det egna omdömet. Om detta fungerade som avsett avväpnades ett mer allmänt motstånd mot propaganda och reklam. Dessutom hade detta ett vidare syfte: gruppstudierna avsåg, likt propaganda, att leda till handling. Gruppdeltagarna skulle, som Aléx sammanfattar, "föra ut sin kunskap till sin närmaste omgivning". ${ }^{100}$ I detta fall inkluderade det att göra personlig propaganda för kooperationen, men det kunde också innebära att föra ut kunskap om det handledningen benämnde propagandafrågor. Deltagarna skulle med andra ord även föra ut förståelsen för hur propaganda och reklam kunde vara ett redskap i kooperationens och demokratins tjänst.

\section{Svaren på propagandafrågorna}

I centrum för denna undersökning har stått ett dilemma som på många sätt var typiskt för mellankrigstidens demokratidiskussioner, nämligen hur en avvägning kunde göras mellan effektivitet och demokratisk legitimitet i en offentlig kommunikation som syftade till att påverka tänkesätt och handlingar. Detta var ett dilemma som tidens till synes allt mer framgångsrika reklam och propaganda aktualiserade, eftersom framgången ofta tycktes undergräva det sakliga utbyte som ett demokratiskt samhällsliv behövde. För KF var detta en viktig fråga som man intog en säregen position till. Anledningen till detta var att kooperationen inte bara var en kommersiell aktör som bedrev omfattande reklam och propaganda utan även hävdade starka demokratiska ideal.

Denna studie visar för första gången hur detta dilemma ställdes på sin spets och hanterades av KF inom ramen för den egna medlemsutbildningen. Kooperationens position behövde förklaras för de mer aktiva medlemmarna, vilka inte bara bar upp hela verksamheten genom dess engagemang $i$ kooperationens demokratiska organisation, utan även förutsattes själva bedriva utåtriktad propaganda för dess sak. I detta syfte utarbetades en handledning i propagandafrågor för KF:s gruppstudieverksamhet. För att visa hur denna medlemsutbildning gick till har undersökningen tagit fasta på konkreta pedagogiska överväganden och praktiker. Dessa har inte studerats i KF:s fall och utgör därtill en aspekt av folkbildning som i tidigare forskning regelmässigt förbisetts till förmån för ideal och programmatiska uttalanden.

Gruppstudierna ägnades i hög grad åt övningar i gemensamma kritiska reflektioner över propagandans roll i samhället samt åt frågan om hur såväl andras som egna åsikter om kooperationen bildats och hur de kunde ställas på en fastare grund. Till

98 Se t.ex. "Ett slag för reklamens egen sak," Reklamnyheterna 1937:11, 2; "Lubbereklam för ny rigg," Dagens Nyheter, 5 Juni, 1936.

99 Se särskilt Sohlenius (1937), 4-12, 50-54.

100 Aléx (2008), 93. 
de rationella förmågorna som övades hörde även att förhålla sig kritisk till folkbildningsauktoriteter som Alf Ahlberg, vars framställningar av reklamens och propagandans hot mot demokratin i boken Tankelivets frigörelse bildade en utgångspunkt för gruppdiskussionerna. Hans envägskommunikation ersattes inte heller av en annan men lika auktoritativ röst från KF. Istället organiserades gruppstudierna för att underbygga ett lärande som inte grundades $i$ en helt uppifrån styrd process, utan som även hade mer horisontella inslag, där deltagarna lärde sig i ömsesidigt utbyte och genom att relatera den lästa litteraturen och de stora samhällsfrågor som togs upp till egna vardagliga erfarenheter.

Studien visar till sist hur kooperationen bidrog till att avväpna den långtgående kritik av reklam och propaganda som bland andra Ahlberg stod för. KF:s hantering av propagandans roll i den moderna demokratin - att skapa sammanhang för medlemmarna att diskutera frågan och upplysa varandra i diskussion, samt att låta en demokratisk organisationsform garantera sanningshalten i den egna propagandan gick bortom såväl Ahlbergs fördömande som reklambranschens självförhärligande. Denna position innebar att KF:s intervention i diskussionerna om demokrati och propaganda underbyggde ett slags kvalificerad och kritisk acceptans för reklam och propaganda - även i dess mer suggestiva former - som i slutändan legitimerande dess närvaro i den kommersiella och politiska offentligheten. I vilken utsträckning detta eller kooperationens i övrigt innovativa användning av reklam i längden tjänade det demokratiska samhället är en annan fråga.

\section{Acknowledgements}

Arbetet med denna artikel har möjliggjorts genom ett bidrag från Ridderstads stiftelse för historisk grafisk forskning. 


\section{Referenser}

Systematiskt genomgångna tidskrifter

Kooperativa gruppen (1929-1934).

Kooperatören (1930-1939).

Vi vill (1934-1939).

Övriga tryckta källor

Affärsekonomi (1935:17). "En ny annonsstil? Affärsekonomis första bordssamtal med 6 reklammän."

Ahlberg, Alf. Tankelivets frigörelse. Stockholm: KF, 1934.

Dagens Nyheter (5 Juni, 1936). "Lubbereklam för ny rigg."

Gruppverksamheten: Vad den är och vill. Stockholm: O. Eklund, 1935.

Hedberg, Anders. Kooperativ propaganda. 2:a uppl., Stockholm: KF, 1928.

Kooperativa förbundets förvaltnings- och revisionsberättelser. Stockholm: KF, 19301940.

Kooperativ upplysning och utbildning: Kommittébetänkande till Kooperativa förbundets kongress år 1931. Stockholm: KF, 1931.

Reklamnyheterna (1937:11). "Ett slag för reklamens egen sak."

Sohlenius, Holter. Propagandafrågor: Handledning för de kooperativa gruppernas diskussioner: Avd. 4-6: Kooperativ och antikooperativ propaganda. Stockholm: KF, 1937.

Stolpe, Herman. Att tänka och diskutera: Bildning och propaganda Stockholm: KF, 1938).

Stolpe, Herman. "Gruppverksamheten", Bokstugan 1936:5.

Stolpe, Herman. Handledning för de kooperativa gruppernas diskussioner: Kooperation - demokrati - diktatur. Stockholm: KF, 1938.

Stolpe Herman. Stark demokrati genom ökade kunskaper: Medlemsupplysningen inom den svenska kooperationen. Stockholm: KF, 1939.

Stolpe, Herman. "Studieplaner och cirkelarbete", Bokstugan 1934:1.

Stolpe, Herman och Holter Sohlenius. Propagandafrågor: Handledning för de kooperativa gruppernas diskussioner. Stockholm: KF, 1935.

Örne, Anders. De sju grundsatserna: Kooperationens program i kort sammanfattning. 6. uppl., Stockholm: KF, 1932.

Örne, Anders. Kooperativa ideer och spörsmål. 2. uppl. Stockholm: KF, 1936.

Örne, Anders. Demokrati. Stockholm: KF, 1931.

\section{Litteratur}

Aléx, Peder. Den rationella konsumenten: KF som folkuppfostrare 1899-1939. Stockholm: Symposion, 1994.

Aléx, Peder. "Gränsöverskridande samarbete: Herman Stolpe och konsumentkooperationen." I Mångsysslare och gränsöverskridare: 13 uppsatser i idéhistoria, red. Bosse Sundin och Maria Göransdotter, 89-102. Umeå: Umeå universitet, 2008.

Auerbach, Jonathan. Weapons of Democracy: Propaganda, Progressivism, and American Public Opinion. Baltimore: Johns Hopkins University Press, 2015. 
Edquist, Samuel. "Studiecirkeln - en demokratisk revolution?" I Utbildningens revolutioner: Till studiet av utbildningshistorisk förändring, red. Anne Berg et al., 139-162. Uppsala: Uppsala Studies of History and Education, 2017.

Edquist, Samuel. "Demarcating Popular Education with Government Subsidies: Sweden 1911-1991." Nordic Journal of Educational History 2, no. 1 (2015), 73-96.

Ekström, Anders. Representation och materialitet: Introduktioner till kulturhistorien. Nora: Nya Doxa, 2009.

Elldin, Harald. Klipp och bakgrunder till kooperativt fostringsarbete under ett halvsekel. Stockholm: KF, 1950.

Ewen, Stuart. PR! A Social History of Spin. New York: Basic Books, 1996.

García, Hugo. "Reluctant Liars? Public Debates on Propaganda and Democracy in Twentieth-Century Britain (ca. 1914-1950)." Contemporary British History 33, no. 2 (2019), 383-404.

Gardeström, Elin. Reklam och propaganda under svenskt 1930-tal. Huddinge: Södertörns högskola, 2018.

Hilson, Mary. "Co-operative History: Movements and Businesses." I A Global History of Consumer Co-operation: Movements and Businesses, red. Mary Hilson, Silke Neunsinger och Greg Patmore, 17-48. Boston: Brill, 2017.

Hilson, Mary. The International Co-operative Alliance and the Consumer Co-operative Movement in Northern Europe, c. 1860-1939. Manchester: Manchester University Press, 2018.

Jonsson, Pernilla. "From Commercial Trickery to Social Responsibility: Marketing in the Swedish Co-operative Movement in the Early Twentieth Century." I A Global History of Consumer Co-operation: Movements and Businesses, red. Mary Hilson, Silke Neunsinger och Greg Patmore, 642-667. Boston: Brill, 2017.

Krantz, Kjell. Alf Ahlberg: En biografi. Ludvika: Dualis, 1998.

Laginder, Ann-Marie, Henrik Nordvall och Jim Crowther, red. Popular Education, Power and Democracy Swedish Experiences and Contributions. Leicester: Niace, 2013.

Nordberg, Karin. Folkhemmets röst: Radion som folkbildare 1925-1950. Eslöv: Symposion, 1998.

Robertson, Nicole. The Co-Operative Movement and Communities in Britain, 19141960: Minding Their Own Business. Routledge: London och New York, 2010.

Ross, Corey. "Mass Politics and the Techniques of Leadership: The Promise and Perils of Propaganda in Weimar Germany." German History 24, no. 2 (2006), 184-211.

Ruin, Olof. Kooperativa förbundet 1899-1929: En organisationsstudie. Stockholm: Rabén \& Sjögren, 1960.

Schwarzkopf, Stefan. "Innovation, Modernisation, Consumerism: The Co-operative Movement and the Making of British Advertising and Marketing Culture, 1890s-1960s." I Consumerism and the Co-operative Movement in Modern British History: Taking Stock, red. Lawrence Black och Nicole Robertson, 197-221. Manchester: Manchester University Press, 2009.

Schwarzkopf, Stefan. "Respectable Persuaders: The Advertising Industry and British Society, 1900-1939." PhD diss., Birkbeck College, University of London, 2008.

Schwarzkopf, Stefan. "Who Said 'Americanization'? The Case of Twentieth-Century Advertising and Mass Marketing from a British Perspective." I Decentering America, red. Jessica C. E. Gienow-Hecht, 23-72. New York: Berghahn, 2007. 
Shaw, Linda. "International Perspectives on Co-operative Education." I Hidden Alternative: Co-Operative Values, Past, Present and Future, red. Anthony Webster, Alyson Brown, David Stewart, John K. Walton och Linda Shaw, 59-77. Manchester: Manchester University Press, 2012.

Sundgren, Per. Kulturen och arbetarrörelsen: Kulturpolitiska strävanden från August Palm till Tage Erlander. Stockholm: Carlssons, 2007.

Swett, Pamela E. Selling Under the Swastika: Advertising and Commercial Culture in Nazi Germany. Stanford: Stanford University Press, 2014.

Tistedt, Petter. Visioner om medborgerliga publiker: Medier och socialreformism på 1930-talet. Höör: Symposion, 2013.

Tistedt, Petter. "Reklam för demokrati? Reklamens politik i mellankrigstidens Sverige." Scandia 84, no. 1 (2019), 65-91.

Vernon, Keith. "History, Citizenship and Co-operative Education, c. 1895-1930." I Mainstreaming Co-Operation: An Alternative for the Twenty-First Century?, red. Anthony Webster, Linda Shaw och Rachel Vorberg-Rugh, 69-89. Manchester: Manchester University Press, 2016.

Westberg, Johannes. "Vad är utbildningshistoria?" Utbildning och demokrati 26, no. 3 (2017), 7-37.

Östling, Johan. Nazismens sensmoral: Svenska erfarenheter i andra världskrigets efterdyning. Stockholm: Atlantis, 2008. 